\title{
Secondary Neoplasms of the Female Lower Genital Tract After Hematopoietic Cell Transplantation
}

\author{
Howard A. Chang, BA' ; Saro H. Armenian, DO, $\mathrm{MPH}^{\mathrm{a}}$; and Thanh H. Dellinger, $\mathrm{MD}^{\mathrm{b}}$
}

\begin{abstract}
Hematopoietic cell transplantation (HCT) results in long-term survival ( $\geq 10$ years) in $85 \%$ of patients who survive transplant-related complications within the first 2 years posttransplant. Transplant survivors, however, are at an increased risk of chronic health conditions compared with the general population, including the emergence of secondary malignant neoplasms. In particular, female transplant survivors may face a greater risk of lower genital tract (cervical, vulvar, or vaginal) neoplasms due to chronic immune dysregulation in the peritransplant and posttransplant environment. Persistent immune suppression may facilitate the carcinogenesis of human papillomavirus (HPV), the causative agent of nearly all cervical cancers and most vulvar and vaginal cancers. Nevertheless, the risk of these cancers has not been sufficiently quantified in female transplant survivors. Small clinical studies have shown that the rate of cervical cytological abnormalities increases after allogeneic HCT, but large population-based studies have not consistently demonstrated an increased risk of secondary cervical cancer after transplant compared with the general population; the risk of developing secondary vulvar or vaginal cancer after transplant remains unclear. A better understanding of the natural history of HPV-associated lower genital tract neoplasms and their transplant-related risk factors would help delineate optimal long-term follow-up protocols in this population. In this systematic review, we summarize the current literature on this topic and discuss the implications for cervical cancer screening and vaccination in female transplant recipients.
\end{abstract}

J Natl Compr Canc Netw 2018;16(2):211-218 doi: 10.6004/jncen.2018.7005

The female lower genital tract (cervix, vulva, vagina) is a common cancer site within the general population. ${ }^{1}$ Cervical cancer is the second most common cancer among women worldwide, while vulvar and vaginal cancers are much rarer, accounting for $7 \%$ of all gynecologic malignancies. ${ }^{2,3}$

More than $90 \%$ of cervical cancers and at least $60 \%$ to $70 \%$ of vulvar and vaginal cancers are caused by the human papillomavirus (HPV), the most common sexually transmitted infection. ${ }^{4-6}$ Because of the viral etiology of most lower genital tract cancers, women who are immunocompromised and thus unable to eliminate HPV or suppress its activity may be at a higher risk of developing these cancers. ${ }^{78}$ For example, solid organ transplant recipients who are on prolonged immunosuppressive therapy are more likely to develop lower

From the aDepartment of Population Sciences, Division of Outcomes Research, and 'Department of Surgery, Division of Gynecologic Surgery, City of Hope National Medical Center, Duarte, California.

Submitted November 13, 2017; accepted for publication January 9, 2018.

The authors have disclosed that they have no financial interests, genital tract precancers and cancers, and these diseases are more aggressive, advance more quickly, and occur earlier in life than in immune-competent women. ${ }^{9-11}$

Hematopoietic cell transplantation (HCT) entails immune dysregulation in both recipients of autologous HCT (auto-HCT) ${ }^{12,13}$ and allogeneic HCT (allo-HCT)..$^{14,15}$ AlloHCT recipients in particular are susceptible to graft-versushost disease (GvHD), a serious inflammatory condition resulting from the immunologic attack of recipient tissue by donor T cells. ${ }^{16}$ Both the acute and chronic manifestations of GvHD play a role in impeding immunologic recovery following HCT. ${ }^{14,15}$ Moreover, patients who develop chronic GvHD often require years of immunosuppressive therapy to treat the condition. ${ }^{17}$ The immune dysregulatory effects of GvHD and the prolonged immunosuppressive therapy used to treat it may provide a physiological milieu condu- 
cive to the reactivation, progression, or acquisition of HPV? ${ }^{?}$ Auto-HCT recipients do not experience the same degree of immune dysregulation because GvHD does not occur in these patients; however, the immune system may still be impaired for at least a year after autoHCT. ${ }^{13}$ These biological underpinnings substantiate a model in which impaired immune surveillance of viral latency facilitates HPV replication en route to progressive lower genital tract disease. ${ }^{\text {? }}$

Ninety percent of immune-competent females infected with HPV will mount an effective immune response to clear the infection within 2 years. ${ }^{18}$ Those who are unable to do so may develop cervical, vulvar, or vaginal dysplasia. Screening with Papanicolaou (Pap) smears detects cytologic abnormalities such as low-grade and high-grade squamous intraepithelial lesions (LSIL and HSIL, respectively). Histology-confirmed koilocytic changes found on colposcopic biopsy are denoted, in increasing severity, as cervical intraepithelial neoplasia grades 1,2 , and 3 (CIN1, CIN2, and CIN3, respectively). Upon incident HPV infection, the transition from cervical dysplasia to invasive cancer is fairly low and slow: only $1 \%, 5 \%$, and $12 \%$ of CIN1, CIN2, and CIN3, respectively, progress to cervical cancer, ${ }^{19}$ with a time frame of at least 5 to 10 years from the incident infection..$^{20}$ Vulvar intraepithelial neoplasia progresses to cancer in $2.7 \%$ to $8.5 \%$ of women. ${ }^{21}$ Limited data are available on the rate of progression from vaginal intraepithelial neoplasia to cancer, due to the rarity of primary vaginal cancer. Importantly, because these low transition rates are reported in immune-competent women, rates of progression to cancer may be higher in female HCT recipients. Prompt detection of lower genital tract neoplasms is therefore paramount to providing clinicians with early intervention opportunities in this high-risk population.

The primary goal of this review is to summarize the current literature describing female lower genital tract neoplasms (dysplasias and cancers) after HCT. This information can provide key information on the potential for HCT-related risk and potentially assist in clinical decision-making on long-term follow-up strategies after HCT.

\section{Methods}

A comprehensive literature review was performed via PubMed encompassing the years 1994 to 2016 to search for articles covering 2 separate but related topics: first, all clinical and population-based studies on occurrence (presentation, incidence, or risk) of cervical, vulvar, and vaginal neoplasms after HCT, and second, all such studies broadened to include any kind of secondary neoplasm after HCT. A standard strategy using advanced search keywords was used with variations of terms (eg, "cervical dysplasia," "cervical neoplasm," "secondary cancers") to incorporate wording differences in the literature. The initial search, along with additional articles identified from published reviews, yielded 355 articles, which were reviewed and screened to exclude 312 articles. Among the remaining 43 articles, 20 were excluded due to lack of cervical, vulvar, or vaginal cases, leaving 23 articles eligible for this review (Figure 1).

\section{Results}

\section{Cervical Dysplasia After HCT}

Our search yielded 4 studies assessing cervical dysplasia after HCT (Table 1). Sasadeusz et al ${ }^{22}$ were the first to show an increased occurrence of abnormal cervical cytology in women after undergoing allo-HCT. They conducted a retrospective analysis of all available pre-HCT and post-HCT Pap smears in 40 recipients of auto-HCT and 24 recipients of allo-HCT at a single center, finding that allo-HCT recipients had a 6.8-fold increased risk of LSIL or HSIL post-HCT compared with the age-matched general population. However, there was no increased risk of cervical dysplasia among auto-HCT recipients compared with the general population. The authors concluded that factors unique to the allogeneic setting - chronic GvHD and/or the requirement of long-term immunosuppressive therapy-likely exacerbated the risk of cervical dysplasia. However, the study was limited by the absence of both data on chronic GvHD severity and details regarding the intensity and duration of immunosuppressive therapy.

In another study of only allo-HCT recipients, Savani et $\mathrm{al}^{23}$ similarly found that patients had greater rates of cervical dysplasia post-HCT compared with pre-HCT. In this study, 35 women who had normal cervical cytology pre-HCT were followed for a median of 7 years after HCT. During the follow-up period, 43\% developed cervical dysplasia, including 20\% with HSIL and 14\% with LSIL, all of which were biopsy-confirmed to be HPV-related (HPV DNA testing was not performed). The au- 


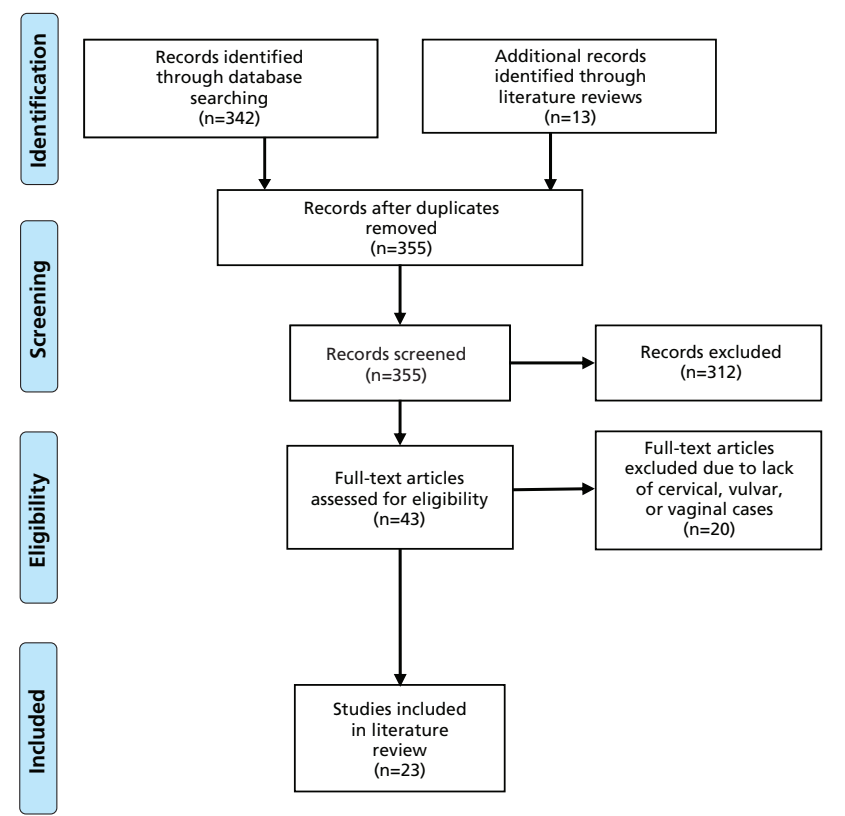

Figure 1. Preferred Reporting Items for Systematic Reviews and Meta-Analyses (PRISMA) flow diagram for the systematic review of secondary cervical, vulvar, and vaginal neoplasms after hematopoietic cell transplantation.

thors also recorded the duration of post-HCT immunosuppressive therapy administered to the patients, finding that prolonged ( $>3$ years) exposure to immunosuppressive agents for management of chronic GvHD resulted in a 4.6-fold increased risk of HPVassociated cervical HSIL or LSIL compared with shorter ( $<3$ years) use of immunosuppressive therapy.
A subsequent study by Wang et $\mathrm{al}^{24}$ followed a larger cohort of allo-HCT recipients (89 women) for a longer period (11 years) post-HCT, and also showed an increased rate of cervical dysplasia post-HCT compared with pre-HCT. All patients were screened on a standardized schedule after HCT and received an average of 6.5 Pap smears per patient during the follow-up period. Compared with pre-HCT smears, there was a 3 -fold increase in the proportion of patients with abnormal smears at any time during the post-HCT follow-up. Among 69 patients who had normal cytology pre-HCT, $16(23 \%)$ showed HSIL and 6 (9\%) showed LSIL postHCT. Most patients (57\%) with persistent HSIL had biopsy-confirmed CIN3. HPV DNA testing in a small subset of patients revealed that 7 of $12(58 \%)$ with HSIL were HPV-positive, but none of the 6 tested patients with LSIL were HPV-positive, implicating nonspecific therapy-related changes. Significant risk factors for the development of HSIL (regardless of HPV status) included unrelated human leukocyte antigen-matched donor and vulvovaginal GvHD.

Most recently, Negri et al ${ }^{25}$ described how in 54 patients with normal cytology pre-allo-HCT, 13 (24\%) showed abnormal cytology post-HCT, including LSIL that persisted on cytologic follow-up 3 to 6 months later in $11 \%$ of the entire cohort. However, they also found that among 3 patients whose initial cytology after HCT revealed atypical squamous cells cannot exclude HSIL (ASC-H), all had negative results on follow-up testing ( 2 had negative histologic follow-up; 1 had cytologic follow-up and a high-risk

\section{Table 1. Studies on Cervical Cytology After HCT (1994-2016)}

\begin{tabular}{|c|c|c|c|c|c|c|c|}
\hline Study & $\begin{array}{l}\text { HCT Period } \\
\text { (Location) }\end{array}$ & $\begin{array}{l}\text { Patients, } \\
\text { N }\end{array}$ & НСТ Tyре & $\begin{array}{l}\text { Median Age } \\
\text { at HCT, } \\
\text { y (range) }\end{array}$ & $\begin{array}{l}\text { Median Follow-Up, } \\
\text { y (range) }\end{array}$ & $\begin{array}{l}\text { Patients With Normal } \\
\text { Pre-HCT Cytology With } \\
\text { Abnormal Post-HCT } \\
\text { Cytology, n (\%) }\end{array}$ & Key Finding ${ }^{b}$ \\
\hline $\begin{array}{l}\text { Sasadeusz } \\
\text { et al, }{ }^{22} 2001\end{array}$ & $\begin{array}{l}\text { 1989-1998 } \\
\text { (Australia) }\end{array}$ & 64 & Allo or auto & $43(22-66)$ & $\begin{array}{l}\text { Auto: } 2.6(0.5-7.5) \\
\text { Allo: } 3.5(0.3-8.8)\end{array}$ & Not reported & $\begin{array}{l}\text { Allo-HCT recipients, but not auto-HCT } \\
\text { recipients, had a significant increase in rate } \\
\text { of LSIL or HSIL post-HCT vs pre-HCT }\end{array}$ \\
\hline $\begin{array}{l}\text { Savani } \\
\text { et al, },^{23} 2008\end{array}$ & $\begin{array}{l}1993-2003 \\
\text { (USA) }\end{array}$ & 38 & Allo & $33(9-60)$ & $7.1(3.8-13.6)$ & $\begin{array}{l}\text { Total: } 15 / \approx 35(\approx 43 \%)^{c} \\
\text { LSIL: } 5 / \approx 35(\approx 14 \%)^{c} \\
\text { HSIL: } 7 / \approx 35(\approx 20 \%)^{c}\end{array}$ & $\begin{array}{l}\text { Chronic GvHD requiring systemic } \\
\text { immunosuppressive therapy } \geq 3 \text { years was } \\
\text { the only risk factor for HPV-positive HSIL or } \\
\text { LSIL after HCT }\end{array}$ \\
\hline $\begin{array}{l}\text { Wang } \\
\text { et al, } 242012\end{array}$ & $\begin{array}{l}1985-2005 \\
\text { (Norway) }\end{array}$ & 89 & Allo & $39(15-59)$ & $11(5-25)$ & $\begin{array}{l}\text { Total: } 44 / 69(64 \%) \\
\text { LSIL: } 6 / 69(8.7 \%) \\
\text { HSIL: } 16 / 69(23 \%)\end{array}$ & $\begin{array}{l}\text { Vulvovaginal GvHD was the only risk factor } \\
\text { for CIN2-3 after HCT }\end{array}$ \\
\hline $\begin{array}{l}\text { Negri } \\
\text { et al, }{ }^{25} 2014\end{array}$ & NR (Italy) & 54 & Allo & NR & NR & $\begin{array}{l}\text { Total: } 13 / 54(24 \%) \\
\text { LSIL: } 6 / 54(11 \%) \\
\text { ASC-H: } 3 / 54(5.6 \%)\end{array}$ & $\begin{array}{l}\text { Follow-up was histologically normal for all } \\
3 \text { patients showing ASC-H on first cytology } \\
\text { post-HCT }\end{array}$ \\
\hline
\end{tabular}

Abbreviations: allo, allogeneic; ASC-H, atypical squamous cells (cannot exclude high-grade lesion); auto, autologous; CIN, cervical intraepithelial neoplasia; GvHD, graftversus-host disease; HCT, hematopoietic cell transplantation; HPV, human papillomavirus; HSIL, high-grade squamous intraepithelial lesion; LSIL, low-grade squamous intraepithelial lesion; NR, not reported.

${ }^{a}$ Column omits percentages of atypical squamous cells of undetermined significance detected on post-HCT cytology.

${ }^{b}$ No cases of cervical cancer were histologically confirmed during the follow-up period in any study.

'Approximations. Cytology was performed after transplant in 35 adult patients only. Authors state that "most patients had normal cervical cytology testing prior to transplantation." 
HPV test, both of which were negative). These initial smears showing ASC-H demonstrated morphology worrisome for invasive cancer, but the authors later recognized these as being false-positives, because the patients had all received high-dose busulfan, a well-known cause of cell atypia appearing on cytology and histology. Therefore, they concluded that even though post-HCT smears may indicate cervical atypia suspicious for cancerous changes, clinicians should wisely determine whether histologic follow-up is warranted to validate these findings.

Despite cohort and treatment differences, all of the aforementioned clinical studies provide evidence that the rate of abnormal cervical cytology increases after allo-HCT. But these studies are limited in important ways. First, small patient populations (38-89 patients) with no detected cervical cancers restricts the ability to draw conclusions about the risk of these cancers post-HCT. Second, the absence of HPV DNA cotesting alongside Pap smears (now standard in the general population) in most of the participants limits the ability to distinguish true cervical dysplasia from transient cytologic atypia. The high HPV negativity rate among patients who were tested implies that significantly larger patient numbers are needed to detect cervical cancer post-HCT.

Demonstrating whether cervical dysplasia tends to progress more readily in HCT recipients compared with the general population may provide further insight into the epidemiology of HPV in immunocompromised women. The evidence suggests that immunocompromised HCT recipients may indeed be more susceptible to cervical progression, because risk factors for cervical dysplasia after HCT include immunologic features such as vulvovaginal GvHD, ${ }^{24}$ unrelated donor, ${ }^{24}$ and long-term use of systemic immunosuppressive therapy. ${ }^{23}$ Future research should seek to compare dysplastic progression and regression rates in HCT recipients using standardized screening schedules with Pap smears and HPV DNA cotesting to minimize detection bias during the follow-up period. Studies should compare these rates with those in the general population, and elucidate the role of HCT-related risk factors in promoting the development of cervical dysplasia.

\section{Cervical Cancer After HCT}

Although few studies have examined cervical dysplasia after HCT, several large cohort studies assessing the risk of secondary cancers after HCT have determined the occurrence of cervical cancer post-HCT (Table 2). Studies by Bhatia et $\mathrm{al}^{26}$ and Shimada et $\mathrm{al}^{27}$ followed 919 and 324 women, respectively, who received either allo-HCT or auto-HCT and discovered a 13.3-fold and 8.6-fold elevated risk of cervical cancer compared with the general population. However, in much larger cohorts (range, 1,765-11,752 women) comprising only allo-HCT recipients, there was no increased risk of cervical cancer post-HCT compared with the general population. ${ }^{28-33}$

The explanation for Bhatia et $\mathrm{al}^{26}$ and Shimada et al's $^{27}$ discovery of an increased cervical cancer risk in a mixed cohort of auto- and allo-HCT recipients presents a challenge in light of the average risk found in studies involving only allo-HCT recipients, who are hypothesized to have the highest risk relative to auto-HCT recipients or the general population. Their positive findings could be explained by their relatively small cohort sizes, in which a small number of detected cervical cancer cases may drive the risk toward significance. Only $4^{26}$ and $2^{27}$ women in these studies, respectively, developed cervical cancer after HCT. Additionally, neither of the 2 patients who developed cervical cancer in Shimada et al's ${ }^{27}$ study had chronic GvHD or were receiving immunosuppressive therapy-the most salient HCT-related risk factors for cervical cancer-when they were diagnosed. Although these findings do not disconfirm the influence of allogeneic factors on HPV progression in the cervix, they nevertheless indicate that allo-HCT may notat least patently-increase the risk of cervical cancer. Notably, each study in Table 2 is limited by a lack of data on HPV types among HCT recipients, which may contribute in a crucial manner toward determining which individuals are most affected by allo-HCT (eg, those with high-risk HPV) versus those who are not (eg, those with low-risk or no detectable HPV).

One possible explanation for why studies have generally not found an increased risk of cervical cancer in allo-HCT recipients is that the duration of follow-up was not sufficiently long enough to detect cervical cancer. The incidence of secondary solid tumors has been shown to peak at approximately 6.8 years after allo-HCT, ${ }^{34}$ and this incidence continues to increase linearly with time for at least 2 decades post-HCT. ${ }^{31}$ The long latency period of secondary solid tumors, particularly cervical cancer, may mean that longer follow-up would allow more time for 
Female Genital Tract Neoplasms After HCT

Table 2. Cervix-Related Findings on Secondary Cancers After HCT (1994-2016)

Study Details

\begin{tabular}{|c|c|c|c|c|c|c|c|c|c|}
\hline \multicolumn{6}{|c|}{ Stuay Detalls } & \multicolumn{4}{|c|}{ Cervix-Kelatea finaings } \\
\hline Study & HCT Period & $\begin{array}{c}\text { Patients, } \\
\text { N }\end{array}$ & НСТ Type & $\begin{array}{l}\text { Median Age } \\
\text { at HCT, } \\
\text { y (range) }\end{array}$ & $\begin{array}{l}\text { Median } \\
\text { Follow-Up, } \\
\text { y (range) }\end{array}$ & $\begin{array}{l}\text { Cervical Cancers } \\
\text { Post-HCT, } n \\
\text { (\% of All Patients) }\end{array}$ & $\begin{array}{l}\text { SIR } \\
(95 \% \mathrm{Cl})\end{array}$ & $\begin{array}{l}\text { Time to Diagnosis } \\
\text { of Cervical Cancer } \\
\text { Post-HCT, y } \\
\text { (Number of Cases) }\end{array}$ & $\begin{array}{l}\text { Cervical } \\
\text { Dysplasia Cases } \\
\text { Post-HCT, } \\
\text { n (Type) }\end{array}$ \\
\hline $\begin{array}{l}\text { Bhatia } \\
\text { et } \text { al, }^{26} 2001\end{array}$ & 1976-1998 & 919 & $\begin{array}{l}\text { Allo or } \\
\text { auto }\end{array}$ & $33.9(1.5-71.5)$ & $3.3(0.1-21.1)$ & $4(0.44)$ & $\begin{array}{l}13.3^{\mathrm{b}} \\
(3.5-29.6)\end{array}$ & $\begin{array}{l}\text { Median: } 3.3 \\
\text { Range: } 1.6-9.7\end{array}$ & 0 \\
\hline $\begin{array}{l}\text { Shimada } \\
\text { et } \mathrm{al}^{27} 2005\end{array}$ & $1981-2000$ & 324 & $\begin{array}{l}\text { Allo or } \\
\text { auto }\end{array}$ & $34(15-70)$ & $5.3(1-19.9)$ & $2(0.62)$ & $\begin{array}{l}8.6^{\mathrm{b}} \\
(1.04-31.01)\end{array}$ & $\begin{array}{l}3.8(1) \\
4.9(1)\end{array}$ & 0 \\
\hline $\begin{array}{l}\text { Ringden } \\
\text { et al, }{ }^{28} 2014\end{array}$ & 1995-2006 & 1,765 & Allo & $53(<1-79)$ & $6(0.1-15.7)$ & $1(0.057)$ & $\begin{array}{l}2.1 \\
(0.05-11.93)\end{array}$ & NR & 0 \\
\hline $\begin{array}{l}\text { Atsuta et al, } \\
2014\end{array}$ & 1990-2007 & 7,149 & Allo & $40(16-85)$ & $\begin{array}{l}69,465 \\
\text { person-years }\end{array}$ & $7(0.098)$ & $\begin{array}{l}1.5 \\
(0.6-3.0)\end{array}$ & $\begin{array}{l}<1(1) \\
1-4(4) \\
5-9(1) \\
\geq 10(1)\end{array}$ & 0 \\
\hline $\begin{array}{l}\text { Majhail et al, } \\
2011\end{array}$ & 1986-2006 & 1,903 & Allo & $\begin{array}{l}29(<1-60) \text { or } \\
36(<1-60)^{c}\end{array}$ & $\begin{array}{l}7(<1-21) \text { or } \\
8(<1-19)^{c}\end{array}$ & $3(0.16)$ & $\begin{array}{l}2.3 \\
(0.48-6.77)\end{array}$ & $\begin{array}{l}<1(1) \\
1-4(1) \\
5-9(1)\end{array}$ & 0 \\
\hline $\begin{array}{l}\text { Rizzo } \\
\text { et al, }{ }^{31} 2009\end{array}$ & 1964-1994 & 11,752 & Allo & $27(0.1-72.4)$ & $\begin{array}{l}36,252 \\
\text { person-years } \\
\text { for women }\end{array}$ & $5(0.043)$ & $\begin{array}{l}1.7 \\
(0.54-3.85)\end{array}$ & $\begin{array}{l}<1(1) \\
1-4(3) \\
\geq 15(1)\end{array}$ & 3 (CIS) \\
\hline $\begin{array}{l}\text { Curtis } \\
\text { et al, } 321997\end{array}$ & 1964-1990 & 7,851 & Allo & 25.5 & $3.5(1-25)$ & $1(0.013)$ & $\begin{array}{l}1.7 \\
(0.54-3.85)\end{array}$ & $1-4(1)$ & 0 \\
\hline $\begin{array}{l}\text { Lowsky } \\
\text { et al,33 } 1994\end{array}$ & 1970-1993 & 248 & Allo & $(17-55)$ & $\begin{array}{l}1,608 \text { person- } \\
\text { years }^{d}(1-24)\end{array}$ & 0 & - & - & $5(\mathrm{CIN})$ \\
\hline $\begin{array}{l}\text { Kolb } \\
\text { et al, }{ }^{35} 1999\end{array}$ & pre-1986 & 433 & $\begin{array}{l}\text { Allo or } \\
\text { auto }\end{array}$ & $21(1-51.9)$ & $10.7(5-22.1)$ & 0 & - & - & 5 (CIS) \\
\hline $\begin{array}{l}\text { Danner-Koptik } \\
\text { et al, }{ }^{36} 2013\end{array}$ & 1987-2003 & 592 & Auto & $8(<1-21)$ & $8(<1-21)$ & $1(0.17)$ & $\begin{array}{l}48^{\mathrm{b}} \\
(1.2-270)\end{array}$ & $<1(1)$ & 0 \\
\hline $\begin{array}{l}\text { Seshadri } \\
\text { et al, }{ }^{37} 2009\end{array}$ & 1987-2006 & 164 & Auto & $50(19-70)$ & 4.8 & $1(0.61)$ & NR & NR & 0 \\
\hline $\begin{array}{l}\text { Brown } \\
\text { et al, }{ }^{38} 2005\end{array}$ & 1982-1997 & 254 & Auto & 44 & 9.5 & 0 & - & - & 1 (HSIL) \\
\hline $\begin{array}{l}\text { Ruiz-Soto } \\
\text { et al, }{ }^{39} 2005\end{array}$ & 1993-2002 & 60 & Auto & $46(18-69)$ & $3(0.5-12)$ & $1(1.7)$ & NR & $9.8(1)$ & 0 \\
\hline
\end{tabular}

Abbreviations: allo, allogeneic; auto, autologous; CIN, cervical intraepithelial neoplasia; CIS, carcinoma in situ; HCT, hematopoietic cell transplantation; HSIL, high-grade squamous intraepithelial lesion; NR, not reported; SIR, standardized incidence ratio.

a Determined by the authors for the entire cohort including both male and female patients, except where specified.

${ }^{\mathrm{b}}$ Statistically significant.

'Study included 2 groups of patients, those with either acute myeloid leukemia in first complete remission or chronic myeloid leukemia in first chronic phase, with their medians and ranges listed respectively.

${ }^{\mathrm{d}}$ Two patients were aged 12 and 13 years. Median age of sample was not provided.

HCT-related factors to exert their maximal influence on cervical HPV. Indeed, some cases of cervical cancer have been diagnosed $\geq 10$ years post-HCT (Table 2). However, insufficient follow-up duration may not entirely explain the apparent absence of increased cervical cancer risk post-HCT, as evidenced by other studies that have shown a relatively short latency ( $0-4$ years) for secondary cervical cancers (Table 2 ).

Collectively, these findings argue against an elevated risk of cervical cancer among female recipients of allo-HCT. However, this conclusion needs to be regarded cautiously, because young children $(<10$ years of age) comprised a substantial fraction of the HCT population in several studies that did not identify an elevated risk. In the largest cohort study by Rizzo et al, ${ }^{31} 4,058$ of 28,874 total HCT recipients $(14 \%)$ were $<10$ years of age. Majhail et $\mathrm{a}^{30}$ reported $6 \%$ of total HCT recipients $<10$ years of age, and
Kolb et $\mathrm{a}^{35}$ included $15 \%$ of female HCT recipients aged $\leq 10$ years. Bhatia et $\mathrm{al}^{26}$ and Ringden et $\mathrm{al}^{28}$ also included very young children, but the proportion of those aged 0 to 10 years was not specified. Furthermore, all of these studies included HCT recipients as young as infants ( $\leq 1$ year of age). Because children between the ages of 0 and 10 years are unlikely to contract HPV during the follow-up period, the number of cervical cancer cases may have been underestimated. These and future studies should therefore consider performing separate analyses for cervical cancer risk after excluding very young patients unlikely to have reached sexual debut.

Finally, the outcomes of small studies suggest no increased risk of cervical cancer after auto-HCT compared with the general population (Table 2). ${ }^{36-39}$ The only study that found an increased risk was based on only 1 case in a pediatric sample. ${ }^{36}$ 


\section{Vulvar and Vaginal Neoplasms After HCT}

Minimal information is available on vulvar and vaginal neoplasms after HCT; studies have been limited by small numbers detected post-HCT and by heterogeneity of follow-up (Table 3). Although an elevated risk of vulvar cancer post-HCT was found in 2 studies, these were based on the occurrence of only 1 case $^{40}$ and 2 cases, ${ }^{28}$ respectively. Other studies have also identified single cases of vulvar dysplasia or cancer, without risk determination. ${ }^{33,34,41}$ There are no available risk assessments for vaginal cancer after HCT due to its rarity; among all the studies we reviewed, only 1 case of vaginal cancer was detected post-HCT. ${ }^{42}$ We are unaware of any studies reporting on the rate of vulvar or vaginal dysplasias after HCT or identifying HCT-related risk factors for their occurrence.

\section{Implications for Screening and Vaccination After HCT}

Existing studies of Pap-detected cervical abnormalities after HCT have not captured any cervical cancers during their respective follow-up periods. ${ }^{22-25}$ This may be due to small sample sizes or the long latency from HPV infection to cervical cancer. Nonetheless, one may question whether abnormal Pap smears post-HCT reliably predicts cancer in HCT recipients without HPV DNA cotesting, because abnormal cytology can occur transiently from non-HPV-related causes such as conditioning therapy. ${ }^{25}$ Important but unaddressed impli- cations exist regarding screening schedules in HCT recipients and whether these should differ from those recommended for the general population. The HPV DNA test is now incorporated into general cervical screening recommendations (Table 4). ${ }^{43}$ We contend that this test should also be part of screening for HCT survivors, potentially replacing cytology-only screening.

Currently, there are no official guidelines for cervical screening in women post-HCT, although consensusbased recommendations suggest Pap smears every 1 to 3 years, ${ }^{44-46}$ which is in contrast to the official recommendations of 3 to 5 years for the general population. ${ }^{43}$ It is unknown whether screening every 1 to 3 years is optimal in HCT survivors, or whether certain subsets of women - for example, those who have extensive vulvovaginal GvHD or who are on protracted immunosuppressive therapy post-HCT-would benefit from more regular screening, and how HPV DNA testing should be incorporated into follow-up strategies for high-risk individuals. For instance, should women who develop vulvovaginal GvHD-which affects at least 25\% to $49 \%$ of women within 2 years after allo-HCT-be screened more regularly, given that the condition may increase the risk of HPV-associated neoplasms? ${ }^{24,47,48} \mathrm{~A}$ modified evidence-based cervical screening schedule already exists for immunocompromised women who are HIV-positive (Table 4). ${ }^{49}$ In a similar fashion, we hope that further research will help guide an evidence-based process to establish guidelines in HCT survivors.

\begin{tabular}{|c|c|c|c|c|c|c|c|c|c|}
\hline \multicolumn{6}{|c|}{ Study Details } & \multicolumn{4}{|c|}{ Vulva- and Vagina-Related Findings } \\
\hline Study & HCT Period & $\begin{array}{c}\text { Patients, } \\
\mathrm{N}\end{array}$ & НСТ Type & $\begin{array}{l}\text { Median } \\
\text { Age at HCT, } \\
\text { y (range) }\end{array}$ & $\begin{array}{l}\text { Median } \\
\text { Follow-Up, } \\
\text { y (range) }\end{array}$ & $\begin{array}{l}\text { Cancers Post-HCT, } \\
\text { n (\% of All Patients) }\end{array}$ & $\begin{array}{l}\text { SIR } \\
(95 \% \mathrm{Cl})\end{array}$ & $\begin{array}{l}\text { Time to Cancer } \\
\text { Diagnosis } \\
\text { After HCT, } \\
\text { y (No. of Cases) }\end{array}$ & $\begin{array}{l}\text { Dysplasia } \\
\text { Cases } \\
\text { Post-HCT, } \\
\text { n (Type) }\end{array}$ \\
\hline \multicolumn{10}{|l|}{ Vulva-related } \\
\hline $\begin{array}{l}\text { Oddou } \\
\text { et } \mathrm{al}^{40} 1998\end{array}$ & 1985-1995 & 65 & Auto & $38(11-61)$ & $4.3(1.8-13)$ & 1 vulvar $(1.5 \%)$ & $\begin{array}{l}287^{\mathrm{b}} \\
(3.73-552)\end{array}$ & $3(1)$ & 0 \\
\hline $\begin{array}{l}\text { Ringden } \\
\text { et } \mathrm{al}^{28} 2014\end{array}$ & 1995-2006 & 1,765 & Allo & $53(<1-79)$ & $6(0.1-15.7)$ & 2 vulvar $(0.11 \%)$ & $\begin{array}{l}18.6^{\mathrm{b}} \\
(2.25-67.02)\end{array}$ & NR & 0 \\
\hline $\begin{array}{l}\text { Deeg } \\
\text { et al, }{ }^{41} 1996\end{array}$ & 1970-1993 & 283 & Allo & $18(1.8-67)$ & $\begin{array}{l}1,498 \\
\text { person-years } \\
\text { for women }\end{array}$ & 1 vulvar $(0.35 \%)$ & NR & NR & 0 \\
\hline $\begin{array}{l}\text { Lowsky } \\
\text { et al, }{ }^{33} 1994\end{array}$ & 1970-1993 & 248 & Allo & $(17-55)$ & $(1-24)$ & 0 & - & - & $1(\mathrm{VIN})$ \\
\hline $\begin{array}{l}\text { Gallagher \& } \\
\text { Forrest, }^{34} 2007\end{array}$ & $1985-2003$ & 416 & Allo & $39(12-65)$ & $1.8(0-19.2)$ & 0 & - & - & 1 (VIN3) \\
\hline \multicolumn{10}{|l|}{ Vagina-related } \\
\hline $\begin{array}{l}\text { Shimoni et al, }{ }^{42} \\
2013\end{array}$ & 1999-2011 & 385 & Allo & $50(17-76)$ & $4.6(1-13)$ & 1 vaginal $(0.26 \%)$ & NR & NR & 0 \\
\hline
\end{tabular}

Abbreviations: allo, allogeneic; auto, autologous; HCT, hematopoietic cell transplantation; NR, not reported; SIR, standardized incidence ratio; VIN, vulvar intraepithelial

${ }^{\text {a }}$ Determined by the authors for the entire cohort including both male and female patients, except where specified.

bstatistically significant. 
Female Genital Tract Neoplasms After HCT

\begin{tabular}{|c|c|c|}
\hline Age Group & General Population ${ }^{\mathrm{b}}$ & HIV-Positive Women ${ }^{c}$ \\
\hline$<21$ years & No screening & $\begin{array}{l}\text { Begin cytologic screening at time of HIV } \\
\text { diagnosis } \\
\text { - If normal, screen again at } 12 \\
\text { and } 24 \text { months } \\
\text { - If all } 3 \text { screens are normal, } \\
\text { screen every } 3 \text { years }\end{array}$ \\
\hline $21-29$ years & $\begin{array}{l}\text { Cytology alone every } \\
3 \text { years }\end{array}$ & Same as for $<21$ years of age \\
\hline $30-65$ years & $\begin{array}{l}\text { Cytology alone every } \\
3 \text { years (acceptable) } \\
\text { Cytology and HPV } \\
\text { DNA cotest every } 5 \\
\text { years (preferred) }\end{array}$ & $\begin{array}{l}\text { Begin cytologic screening at time of HIV } \\
\text { diagnosis (with optional HPV DNA cotest) } \\
\text { If screening by cytology alone: } \\
\text { - If normal, screen again at } 12 \\
\text { and } 24 \text { months } \\
\text { - If all } 3 \text { screens are normal, } \\
\text { screen every } 3 \text { years } \\
\text { If screening by cytology and HPV DNA } \\
\text { cotest: } \\
\text { - If normal, screen every } 3 \text { years }\end{array}$ \\
\hline$>65$ years & $\begin{array}{l}\text { No screening if: } \\
\text { - Negative prior } \\
\text { screening } \\
\text { - No history of } \\
\text { CIN2+ in past } 20 \\
\text { years }\end{array}$ & Same as for $30-65$ years of age \\
\hline
\end{tabular}

Abbreviations: CIN, cervical intraepithelial neoplasia; HPV, human papillomavirus.

additional follow-up diagnostic measures are recommended in the event of any positive cytological screening or HPV testing results, including colposcopic follow-up in certain cases (guidelines not listed).

becommendations from the American Cancer Society, American Society for Colposcopy and Cervical Pathology, and American Society for Clinical Pathology (ACS-ASCCP-ASCP) Cervical Cancer Guideline Committee.43

'Recommendations from the Centers for Disease Control and Prevention, National Institutes of Health, and the HIV Medicine Association (CDCNIH-HIVMA) Panel on Opportunistic Infections in HIV-Infected Adults and Adolescents ${ }^{49}$

${ }^{d}$ Defined as 3 consecutive negative cytology results or 2 consecutive negative cotest results within the previous 10 years, with the most recent tested performed within the past 5 years.

Finally, we highlight that a clearer understanding of the role of HCT in HPV acquisition and progression will inform vaccination guidelines in HCT survivors, for whom there are presently no immunogenicity or safety data regarding the HPV vaccine. Significant declines in the occurrence of high-grade cervical, vulvar, and vaginal neoplasms in multiple populations around the world have been attributed to the HPV vaccine. ${ }^{50} \mathrm{How}$ ever, the rate of HPV vaccination has remained low in childhood cancer survivors, a group that may experi- ence significant long-term benefits from the vaccine. ${ }^{2}$ A study in Texas found that female pediatric cancer survivors aged 13 to 17 years do not begin the 3 -dose HPV vaccine series as commonly as the general population (36\% vs 57\%). ${ }^{51,52}$ Another study in Tennessee found that female pediatric cancer survivors aged 9 to 17 years were less likely to initiate $(32.6 \%)$ or complete $(17.9 \%)$ the HPV vaccine series compared with healthy age-matched controls $(34.3 \%$ initiated and $20.0 \%$ completed). ${ }^{53}$ Thus, the effort to elucidate the incidence, risk, and risk factors associated with female lower genital tract neoplasms may provide clinical evidence of HCTrelated risks critical to improving the rate of vaccine uptake among young eligible women.

\section{Conclusions}

Small clinical studies suggest that cervical dysplasia increases in women after allo-HCT. This observation is supported by our current understanding of the HPVrelated causes of cervical carcinogenesis, a process that may be facilitated by immune dysregulation in the peri- and post-allo-HCT setting. But despite this finding, large population-based studies generally do not show a greater risk of subsequent cervical cancer in allo-HCT recipients compared with the general population. Post-HCT cervical dysplasia may indeed be the transient result of transplant conditioning rather than HPV progression, and even true HPV-related dysplasias often revert to a normal presentation upon HPV clearance. ${ }^{18}$ The occurrence of vulvar and vaginal neoplasms, being much rarer than their cervical counterparts, has not been adequately studied post-HCT. Further elucidating the role of HCT in the progression of female lower genital tract neoplasms will be an important step towards clarifying optimal screening and vaccination measures in vulnerable patients.

\section{References}

1. Siegel RL, Miller KD, Jemal A. Cancer statistics, 2017. CA Cancer J Clin 2017;67:7-30.

2. Klosky JL, Gamble HL, Spunt SL, et al. Human papillomavirus vaccination in survivors of childhood cancer. Cancer 2009;115:5627-5636.

3. U.S. Cancer Statistics Working Group. United States Cancer Statistics: 1999-2014 Incidence and Mortality Web-based Report. Atlanta: U.S. Department of Health and Human Services, Centers for Disease Control and Prevention and National Cancer Institute; 2017. Available at: www. cdc.gov/uscs. Accessed January 12, 2018.

4. Walboomers JM, Jacobs MV, Manos MM, et al. Human papillomavirus is a necessary cause of invasive cervical cancer worldwide. J Pathol 1999;189:12-19.

5. Monk BJ, Burger RA, Lin F, et al. Prognostic significance of human papillomavirus DNA in vulvar carcinoma. Obstet Gynecol 1995;85(5 Pt 1):709-715

6. Alemany L, Saunier M, Tinoco L, et al. Large contribution of human papillomavirus in vaginal neoplastic lesions: a worldwide study in 597 samples. Eur J Cancer 2014;50:2846-2854.

7. Maglennon GA, Doorbar J. The biology of papillomavirus latency. Open Virol J 2012;6:190-197.

8. Maglennon GA, McIntosh PB, Doorbar J. Immunosuppression facilitates the reactivation of latent papillomavirus infections. J Virol 2014;88:710-716. 
9. Hinten F, Meeuwis KA, van Rossum MM, de Hullu JA. HPV-related (pre)malignancies of the female anogenital tract in renal transplant recipients. Crit Rev Oncol Hematol 2012;84:161-180.

10. Meeuwis KA, van Rossum MM, van de Kerkhof PC, et al. Skin cancer and (pre)malignancies of the female genital tract in renal transplant recipients. Transpl Int 2010;23:191-199.

11. Chin-Hong PV, Kwak EJ. Human papillomavirus in solid organ transplantation. Am J Transplant 2013;13(Suppl 4):189-200.

12. Porrata LF, Litzow MR, Markovic SN. Immune reconstitution after autologous hematopoietic stem cell transplantation. Mayo Clin Proc 2001;76:407-412.

13. Steingrimsdottir $\mathrm{H}$, Gruber $\mathrm{A}$, Bjorkholm M, et al. Immune reconstitution after autologous hematopoietic stem cell transplantation in relation to underlying disease, type of high-dose therapy and infectious complications. Haematologica 2000;85:832-838.

14. Williams KM, Gress RE. Immune reconstitution and implications for immunotherapy following haematopoietic stem cell transplantation. Best Pract Res Clin Haematol 2008;21:579-596.

15. Fujimaki K, Maruta A, Yoshida M, et al. Immune reconstitution assessed during five years after allogeneic bone marrow transplantation. Bone Marrow Transplant 2001;27:1275-1281.

16. Blazar BR, Murphy WJ, Abedi M. Advances in graft-versus-host disease biology and therapy. Nat Rev Immunol 2012;12:443-458.

17. Garnett C, Apperley JF, Pavlu J. Treatment and management of graftversus-host disease: improving response and survival. Ther Adv Hematol 2013;4:366-378.

18. Plummer M, Schiffman M, Castle PE, et al. A 2-year prospective study of human papillomavirus persistence among women with a cytological diagnosis of atypical squamous cells of undetermined significance or lowgrade squamous intraepithelial lesion. J Infect Dis 2007;195:1582-1589.

19. Schiffman MH, Brinton LA. The epidemiology of cervical carcinogenesis. Cancer 1995;76(10 Suppl):1888-1901.

20. Majhail NS, Rizzo JD, Lee SJ, et al. Recommended screening and preventive practices for long-term survivors after hematopoietic cell transplantation. Biol Blood Marrow Transplant 2012;18:348-371.

21. van de Nieuwenhof HP, Massuger LF, van der Avoort IA, et al. Vulvar squamous cell carcinoma development after diagnosis of VIN increases with age. Eur J Cancer 2009;45:851-856.

22. Sasadeusz J, Kelly H, Szer J, et al. Abnormal cervical cytology in bone marrow transplant recipients. Bone Marrow Transplant 2001;28:393397.

23. Savani BN, Stratton $P$, Shenoy A, et al. Increased risk of cervical dysplasia in long-term survivors of allogeneic stem cell transplantationimplications for screening and HPV vaccination. Biol Blood Marrow Transplant 2008;14:1072-1075.

24. Wang $Y$, Brinch $L$, Jebsen $P$, et al. A clinical study of cervical dysplasia in long-term survivors of allogeneic stem cell transplantation. Biol Blood Marrow Transplant 2012;18:747-753.

25. Negri G, Herz M, Deola S, et al. Abnormal cervical cytology after allogeneic bone marrow transplantation. Am J Clin Pathol 2014;142:222226.

26. Bhatia $\mathrm{S}$, Louie $\mathrm{AD}$, Bhatia $\mathrm{R}$, et al. Solid cancers after bone marrow transplantation. J Clin Oncol 2001;19:464-471.

27. Shimada K, Yokozawa T, Atsuta Y, et al. Solid tumors after hematopoietic stem cell transplantation in Japan: incidence, risk factors and prognosis. Bone Marrow Transplant 2005;36:115-121.

28. Ringden $O$, Brazauskas $R$, Wang $Z$, et al. Second solid cancers after allogeneic hematopoietic cell transplantation using reduced-intensity conditioning. Biol Blood Marrow Transplant 2014;20:1777-1784.

29. Atsuta Y, Suzuki R, Yamashita T, et al. Continuing increased risk of oral/ esophageal cancer after allogeneic hematopoietic stem cell transplantation in adults in association with chronic graft-versus-host disease. Ann Oncol 2014;25:435-441.

30. Majhail NS, Brazauskas R, Rizzo JD, et al. Secondary solid cancers after allogeneic hematopoietic cell transplantation using busulfan-cyclophosphamide conditioning. Blood 2011;117:316-322.

31. Rizzo JD, Curtis RE, Socie G, et al. Solid cancers after allogeneic hematopoietic cell transplantation. Blood 2009;113:1175-1183.

32. Curtis RE, Rowlings PA, Deeg HJ, et al. Solid cancers after bone marrow transplantation. N Engl J Med 1997;336:897-904.

33. Lowsky R, Lipton J, Fyles G, et al. Secondary malignancies after bone marrow transplantation in adults. J Clin Oncol 1994;12:2187-2192.
34. Gallagher G, Forrest DL. Second solid cancers after allogeneic hematopoietic stem cell transplantation. Cancer 2007;109:84-92.

35. Kolb HJ, Socie G, Duell T, et al. Malignant neoplasms in long-term survivors of bone marrow transplantation. Late Effects Working Party of the European Cooperative Group for Blood and Marrow Transplantation and the European Late Effect Project Group. Ann Intern Med 1999;131:738-744.

36. Danner-Koptik KE, Majhail NS, Brazauskas R, et al. Second malignancies after autologous hematopoietic cell transplantation in children. Bone Marrow Transplant 2013;48:363-368.

37. Seshadri T, Pintilie M, Kuruvilla J, et al. Incidence and risk factors for second cancers after autologous hematopoietic cell transplantation for aggressive non-Hodgkin lymphoma. Leuk Lymphoma 2009;50:380-386.

38. Brown JR, Yeckes H, Friedberg JW, et al. Increasing incidence of late second malignancies after conditioning with cyclophosphamide and total-body irradiation and autologous bone marrow transplantation for non-Hodgkin's lymphoma. J Clin Oncol 2005;23:2208-2214.

39. Ruiz-Soto R, Sergent G, Gisselbrecht C, et al. Estimating late adverse events using competing risks after autologous stem-cell transplantation in aggressive non-Hodgkin lymphoma patients. Cancer 2005;104:27352742 .

40. Oddou S, Vey N, Viens P, et al. Second neoplasms following high-dose chemotherapy and autologous stem cell transplantation for malignant lymphomas: a report of six cases in a cohort of 171 patients from a single institution. Leuk Lymphoma 1998;31:187-194.

41. Deeg HJ, Socie G, Schoch G, et al. Malignancies after marrow transplantation for aplastic anemia and fanconi anemia: a joint Seattle and Paris analysis of results in 700 patients. Blood 1996;87:386-392.

42. Shimoni A, Shem-Tov N, Chetrit A, et al. Secondary malignancies after allogeneic stem-cell transplantation in the era of reduced-intensity conditioning; the incidence is not reduced. Leukemia 2013;27:829-835.

43. Saslow D, Solomon D, Lawson HW, et al. American Cancer Society, American Society for Colposcopy and Cervical Pathology, and American Society for Clinical Pathology screening guidelines for the prevention and early detection of cervical cancer. CA Cancer J Clin 2012;62:147-172.

44. Nguyen ML, Flowers L. Cervical cancer screening in immunocompromised women. Obstet Gynecol Clin North Am 2013;40:339-357.

45. Majhail NS, Rizzo JD, Lee SJ, et al. Recommended screening and preventive practices for long-term survivors after hematopoietic cell transplantation. Biol Blood Marrow Transplant 2012;18:348-371.

46. Bhatia S, Armenian SH, Landier W. How I monitor long-term and late effects after blood or marrow transplantation. Blood 2017;130:13021314 .

47. Spinelli S, Chiodi S, Costantini S, et al. Female genital tract graftversus-host disease following allogeneic bone marrow transplantation. Haematologica 2003;88:1163-1168

48. Zantomio D, Grigg AP, MacGregor L, et al. Female genital tract graftversus-host disease: incidence, risk factors and recommendations for management. Bone Marrow Transplant 2006;38:567-572.

49. Guidelines for the Prevention and Treatment of Opportunistic Infections in HIV-Infected Adults and Adolescents. Available at: http:// aidsinfo.nih.gov/contentfiles/lvguidelines/adult_oi.pdf. Accessed November 10, 2017

50. Castle PE, Maza M. Prophylactic HPV vaccination: past, present, and future. Epidemiol Infect 2016;144:449-468.

51. Hoffman L, Okcu MF, Dreyer ZE, et al. Human papillomavirus vaccination in female pediatric cancer survivors. J Pediatr Adolesc Gynecol 2012;25:305-307.

52. Centers for Disease Control and Prevention (CDC). National and state vaccination coverage among adolescents aged 13-17 years-United States, 2012. MMWR Morb Mortal Wkly Rep 2013;62:685-693.

53. Klosky JL, Russell KM, Canavera KE, et al. Risk factors for non-initiation of the human papillomavirus vaccine among adolescent survivors of childhood cancer. Cancer Prev Res (Phila) 2013;6:1101-1110. 